\title{
11. THE FORAMINIFERA OF SITES 68 TO 75
}

\author{
J. P. Beckmann, Federal School of Technology, Zurich, Switzerland
}

\section{CONTENTS}

Introduction

Composition and Preservation of the Faunas

Biostratigraphy

Species List and Taxonomic Notes

References

Illustrations

\section{INTRODUCTION}

A total of 930 samples was collected during the cruise in October and November, 1969. On the average, one sample was taken for each section of a barrel. Where core recovery was complete, this resulted in a sampling interval of about 1.5 meters. Closer sampling was carried out near lithologic boundaries. An additional sample was usually available from the core catcher (representing the very bottom of a core). Average sample size was about 10 cubic centimeters, except for the core catcher sample, which was usually largermostly 20 to 30 cubic centimeters. The samples were either directly washed in water, or first soaked in a solution of sodium pyro-phosphate in 15 per cent hydrogen peroxide. The success of this treatment was generally good, but with the more indurated rocks it had to be repeated up to five times. The hardest samples of Sites 70 and 71 could only be studied in thin section. The washed residues were examined and are now stored in the two fractions retained by the 80 and 230 mesh sieve.

Because of time limitation, it was not possible to make a detailed faunal study of all samples. The main objectives were therefore a preliminary survey of the composition and preservation of the faunas, the determination of the ranges of the stratigraphic marker species, and a biostratigraphic zonation of the cored intervals. A more complete analysis of the benthonic foraminifera and a paleo-ecological interpretation is planned for a later study.

The author wishes to thank H. M. Bolli (Zurich, Switzerland) for his constant support and valuable advice before and after the cruise. He also received help from J. Kuhn, H. Thierstein and P. Britschgi (Federal School of Technology, Zurich) in making faunal assemblage slides and drafting the tables. H. Franz prepared the scanning electron micrographs.

\section{COMPOSITION AND PRESERVATION OF THE FAUNAS}

It is evident to the reader of the lithologic core descriptions in the present volume that the sediments in this part of the Equatorial Pacific are essentially composed of remains of organisms. Most of the constituents of the washed residues are either calcareous (foraminifera, ostracods, echinoid spines) or siliceous (Radiolaria, diatoms, sponge spicules). Other minor components are fish debris and arenaceous foraminifera. The most abundant fossils in the Central Pacific samples are the Radiolaria. The foraminifera occupy the second place, and they are the major constituent in predominantly calcareous residues. Diatoms, echinoid spines, and ostracods are always a minor element. The same applies generally to fish teeth and bones, but in some samples of Site 68 and the upper part of Site 75, where other microfossils were presumably dissolved, they occur in large numbers. Also in these samples, there is often a concentration of authigenic minerals (mainly phillipsite) and nodules.

Some essential data concerning the distribution of the foraminifera at the various drilling sites are summarized in range charts contained in the appropriate Site Reports (Chapters 3-10). These charts show in the third column from the left the percentage of foraminifera in the total fauna retained on the 80 mesh sieve. Because the foraminifera are usually concentrated in the coarser fraction, these percentages are higher than they would be in the total sample, but are still considered useful for showing vertical and lateral 
variations. A similar semi-quantitative procedure has recently been used by Berggren and Boersma (1969). The next column to the right on the charts shows the planktonic/benthonic ratios among the foraminifera. To a certain degree, this curve runs parallel to the one on the left. Notable exceptions are the relatively rich benthonic faunas in the Eocene of Sites 72 to 74 . The third curve shows the visible solution effects on the foraminifera, classified qualitatively as strong, moderate, weak, or absent. This property is sometimes difficult to assess, particularly where highly corroded and perfectly preserved specimens occur together in the same sample Also, this method cannot take account of the specimens which have been dissolved away completely. Generally speaking, the solution effects on the shells are more noticeable in the younger parts of the stratigraphic section (Upper Miocene to Recent) even in richly calcareous samples. In the Oligocene and Eocene, on the other hand, we often find poor assemblages consisting of large, thick-walled specimens without visible signs of corrosion. It appears that calcium carbonate solution affected the shells differently in the Eocene and Oligocene than later, although it was probably active at all times. Generally, the sequence in which foraminifera disappear from partially dissolved samples is similar to that shown by Berger (1968).

The relatively rich and well-preserved benthonic faunas in the Oligocene and Eocene of Sites 69 and 70 are often associated with abundant Radiolaria. There is a striking resemblance between these faunas and those of the contemporaneous radiolarian marls of Barbados (Beckmann, 1954). Many of the species are the same for both areas. This suggests the presence of a free waterway between the Central Pacific and the Caribbean region at that time and possibly also similar oceanographic conditions.

The cross section on Figure 1 clearly shows a gradual increase in the foraminiferal content of the samples from Site 69 to Site 75 . There are also distinct vertical variations in the percentage of foraminifera. Some of the maxima and minima can be correlated through several sites, especially near the Eocene/Oligocene boundary, in the Upper Oligocene of Sites 69 to 71, and in the Upper Miocene of Sites 71 to 73 (74?). Some of the predominantly siliceous levels, particularly in the Upper Miocene and at the Eocene/Oligocene boundary, appear to be associated with unconformities. Figure 1 also confirms some of the essential features of the distribution of the Central Pacific sediments discussed elsewhere in this volume. Such features include the great thickness of the Middle Miocene to Recent deposits accumulated in the equatorial belt (Sites 71 to 73 ), the relatively constant thicknesses in the Oligocene and Lower Miocene, and the N-S shift (from Site 70 to Site 73) of the area of maximum sediment thickness from the Oligocene to the Quaternary. This shift, as well as the intermittent coring in various parts of the holes, is one of the reasons why none of the sites by itself gives the best record of the entire Tertiary foraminiferal biostratigraphy. However, a nearly ideal composite section can be constructed by combining the following three intervals: Site 72 , depth 0 to 52 meters, for the Quaternary to the Pliocene; Site 71, depth 18 to 474 meters, for the Miocene and uppermost Oligocene; and Site 74 , depth 41 to 102 meters, for the Oligocene and Eocene.

\section{BIOSTRATIGRAPHY}

The foraminiferal assemblages of the Leg 8 sites contain many well known planktonic species, the greater part of which have a worldwide distribution. They all appear to be warm water faunas, and have already been used extensively for the biostratigraphic subdivision of the Tertiary. It is therefore possible in the present report to follow the well known zonal schemes of Bolli (1957a, 1957b, 1966) and of Banner and Blow (1965, emended by Blow, 1969). From the Middle Eocene up to the Middle Miocene, the system elaborated by Bolli (which Banner and Blow follow closely) is essentially used. In the Upper Miocene and Pliocene, however, it was found that the most important markers used by Bolli and Bermudez (1965) and by Bolli (DSDP Leg 4 Report on Foraminifera, 1970) were either rare or absent in the Pacific. This applies particularly to Globorotalia exilis, G. margaritae and $G$. miocenica. In the younger Neogene beds, the units defined by Banner and Blow are therefore more suitable (see also Parker, 1967). Because of their brevity, Banner and Blow's letter and number symbols were found convenient for usage in charts and lists and for communication among the scientific team of the cruise.

The biostratigraphic units as they are used in this report are listed on Table 1 . This table also includes references to the zone definitions followed here and shows the age boundaries adopted throughout the present report. In some cases, a choice had to be made between different definitions of zone boundaries or they had to be adjusted to the particular conditions encountered in the Central Equatorial Pacific, as will be explained below. These adjustments do not significantly alter the established biostratigraphic framework.

The author has not followed a system of datum levels, such as the ones proposed by Jenkins (1966) or Berggren (1969). For initial sample determination on shipboard, and also for the dating of spot cores, a sequence of zones is considered more practical. The utility of datum levels cannot be doubted, particularly in intercontinental correlation, but it is unfortunate that some of the most important groups used in datum level correlation, such as Pseudohastigernia, 


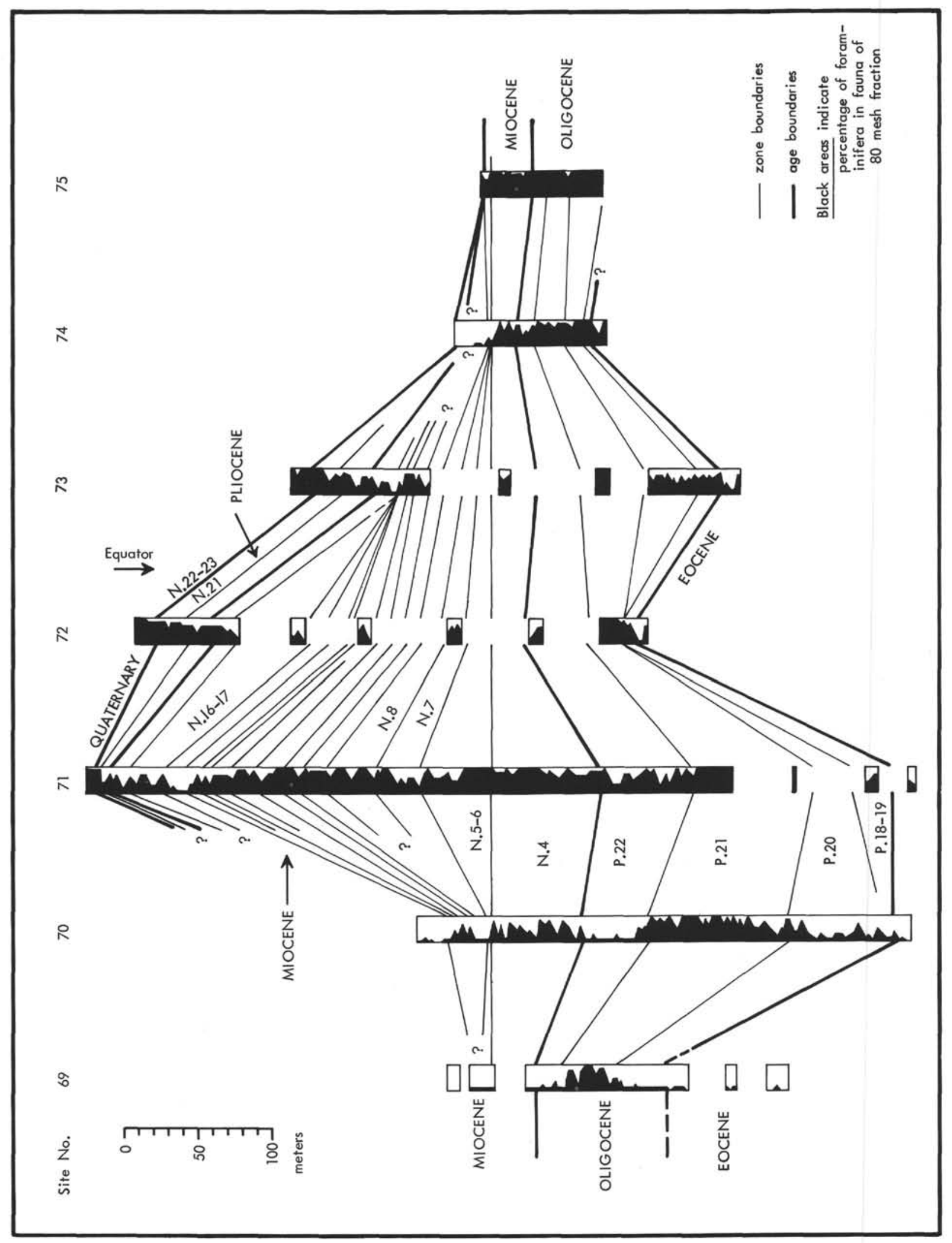

Figure 1. Correlation of foraminiferal zone boundaries and variations in foraminiferal content between Sites 69 and 75. 
TABLE 1

Biostratigraphic Subdivisions and Definitions Adopted in This Report

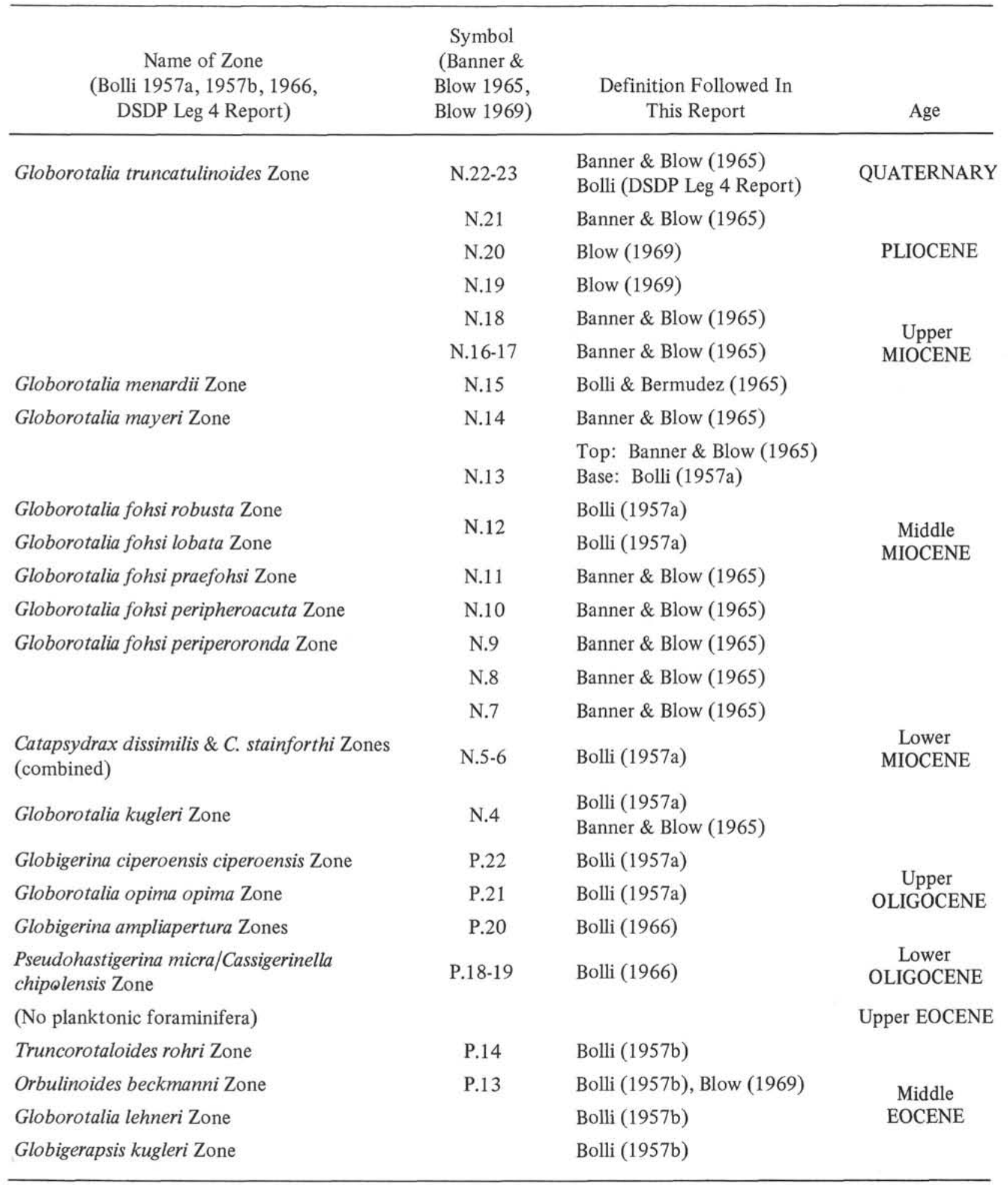


Globigerinoides, and Orbulina are among those most affected by calcium carbonate solution in the Central Pacific samples.

Some explanations are necessary in order to calrify the meaning of the biostratigraphic units shown on Table 1. In the Middle Eocene, the definitions and names of Bolli (1966) are adopted with the exception of the former Porticulasphaera mexicana Zone which is now called the Orbulinoides beckmanni Zone due to a recent taxonomic change. No suitable planktonic foraminifera were found to define the planktonic zones of the Upper Eocene. At most sites, the top of the Eocene is approximately determinable by the highest occurrence of a few characteristic benthonic foraminifera, such as Nuttallides truempyi, Alabamina dissonata and Spiroplectammina trinitatensis. The Eocene samples are also characterized by the presence of large numbers of undetermined small calcareous tubes (diameter 0.1 to 0.2 millimeter).

In the Oligocene, the lowest zone extends up to the extinction level of Pseudohastigerina barbadoensis. This interval corresponds to Banner and Blow's units P. 18 and P. 19. These two units could not be separated, either because P. 18 is missing or because the critical species such as Globigerina angiporoides, $G$. sellii and $G$. tapuriensis are absent for other reasons. The top of the Globigerina ampliapertura Zone (P. 20) is here defined by the earliest appearance of Globorotalia opima opima, not Globigerina ciperoensis angulisuturalis as suggested by Blow (1969). The latter species is found only rarely in exceptionally wellpreserved samples and is therefore not a suitable marker. Blow (1969) thinks that its first appearance might be slightly higher than that of Globorotalia opima opima. For the Globigerina ciperoensis ciperoensis Zone (P. 22) and the Globorotalia kugleri Zone (N. 4), Bolli's definitions are again used. It should be noted that the concept of N. 4 is that of the original definition by Banner and Blow. The later emendation by Blow (1969) is less practicable here, because Globigerinoides primordius is too scarce to define a reliable stratigraphic boundary.

The Catapsydrax dissimilis and $C$. stainforthi Zones (N. 5 and N.6) are here combined because of the absence of Globigerinatella insueta which is essential for the definition of the base of N. 6. For the same reason, Bolli's Globigerinatella insueta Zone is not used; the units N. 7 and N. 8 of Banner and Blow are adopted instead. As already mentioned, the Orbulina datum, which defines the base of N. 9, is usually not a reliable marker in deep sea sediments. It can be approximately located in Site 71 only.

In the succeeding zones (up to N. 12), we find an excellent record of the Globorotalia fohsi lineage first described by Bolli (1950). The taxonomic problems involved here are briefly discussed in the attached Species List. Units N. 10, N. 11 and N. 12 of Banner and Blow have the advantage of being defined by the successive appearance of distinct morphologic characters (irrespective of species or subspecies nomenclature):

Base N. 10: Earliest appearance of specimens with a sharp periphery ( $G$. fohsi peripheroacuta).

Base N. 11: Earliest appearance of a keel in the final whorl.

Base N. 12: Earliest appearance of fully keeled specimens. This boundary appears to be very close to the base of Bolli's $G$. f. lobata Zone.

In the Central Pacific sections, unit N. 12 can be subdivided without difficulty into the $G$. fohsi lobata and $G$. fohsi robusta Zones (sensu Bolli, 1950, 1957a). The top of N. 12 is here chosen as the top of the $G$. $f$. robusta Zone, rather than the first evolutionary appearance of Sphaeroidinellopsis subdehiscens as proposed by Banner and Blow (1965). The writer was unable to trace this evolution in the available samples. Because of the scarcity of Globigerinoides in deep sea samples, it was found more convenient to use the first appearance of Globigerina nepenthes as the base of the Globorotalia mayeri Zone (N. 13/N. 14 boundary), and not the extinction level of Globigerinoides "ruber" (= subquadratus) as originally proposed by Bolli (1957a).

The interval between the top of the Globorotalia menardii Zone (N. 15) and the first appearance of Globorotalia tumida 18) is here combined into one unit (N. 16-17). Until Banner and Blow present the essential documentation of their proposed lineage Globorotalia merotumida-plesiotumida-tumida, it is liable to misinterpretation. The author has therefore refrained from using $G$. plesiotumida to distinguish N. 17, although specimens resembling the drawing of the holotype occur in some samples below the base of N. 18 (see Species List).

The three Pliocene zones N. 19, N. 20 and N. 21 (N. 20 emended in Blow, 1969) are easily distinguishable in Site 72 . In Sites 71 and 73 , the first appearances of Globorotalia pseudopima and G. tosaensis are practically coincident, making it difficult to separate N. 20.

In the Quaternary, no clear distinction between units N. 22 and N. 23 could be made. Of the markers for N. 23 proposed by Banner and Blow (1965), Globigerina calida (sensu stricto) is too rare, and Sphaeroidinella dehiscens "excavata" is morphologically not distinct enough to allow a separation of this zone. The most conspicuous and reliable stratigraphic break within the Quaternary appears to be a change in coiling of Pulleniatina spp. from random to dextral (Hays et al., 1969). 
The present study of the Equatorial Pacific samples has proved the utility of the existing biostratigraphic schemes based on planktonic foraminifera. The desired accuracy of the boundaries could not always be achieved because of mostly inevitable limitations, such as, incomplete core recovery, contamination during the drilling, and calcium carbonate solution.

The foraminiferal range charts in the Site Reports show for each site the stratigraphic ranges of the important marker species, the boundaries of the zones, and the ages as determined by the foraminifera. These ranges are drawn as uninterrupted lines throughout the cored intervals, and therefore do not show whether a species is present or absent in a particular sample. The only exceptions are some species of Globorotalia and Pulleniatina where the preferred coiling direction is indicated with "s" (sinistral) or " $d$ " (dextral).

Figure 1 shows the site to site correlations of the zone boundaries.

\section{SPECIES LIST AND TAXONOMIC NOTES}

This is a list of the species of foraminifera mentioned in the text and on the range charts contained in the Site Reports. It contains references to the original description, to subsequent emendations or designations of types, and occasional comments on their taxonomy and morphology. The species designated with open nomenclature are illustrated on Plate 1.

\section{Planktonic Foraminifera}

Cassigerinella chipolensis (Cushman \& Ponton). Cassidulina chipolensis Cushman \& Ponton, 1932, Florida Geol. Surv. Bull. 9, p. 89, pl. 15, fig. 2.

Catapsydrax dissimilis (Cushman \& Bermudez). Globigerina dissimilis Cushman \& Bermudez, 1937, Contrib. Cushman Lab. Foram. Res., vol. 13, p. 25, pl. 3 , figs. 4-6. In this preliminary study, the species was conceived in a very wide sense, without consideration of the shape of the bulla. It includes the subspecies of C. dissimilis and $C$. unicavus listed by Blow (1969) under nos. 80, 81, 94 and 95.

Chiloguembelina cubensis (Palmer).

Gumbelina cubensis Palmer, 1934, Mem. Soc. Cub. Hist. Nat., vol. 8, p. 74, textfigs. 1-6.

Clavatorella bermudezi (Bolli).

Hastigerinella bermudezi Bolli, 1957a, p. 112, pl. 25, fig. 1 .

Globigerapsis index (Finlay).

Globigerinoides index Finlay, 1939, Trans. Roy. Soc. New Zealand, vol. 69, p. 125, pl. 14, figs. 85-88. Holotype refigured by Hornibrook (1958, p. 34, pl. 1, figs. 11-13).
Globigerina angiporoides Hornibrook.

G. angiporoides Hornibrook, 1965, New Zealand Geol. Surv., Paleon. Bull. 34 , no. 1, p. 145, fig. 3 .

Globigerina calida Parker.

G. calida Parker, 1962, Micropaleontology., vol. 8, p. 221, pl. 1, fig. 12 (not figs. 9, 10,11). The restricted definition of $G$. calida calida by Blow $(1969$, p. 380 , pl. 13 , figs. 9,10 ) is followed here.

Globigerina ciperoensis angulisuturalis Bolli.

G. c. angulisuturalis Bolli, 1957a, p. 109, pl. 22, fig. 11.

Globigerina ciperoensis ciperoensis Bolli.

G. ciperoensis Bolli, 1954, Contrib. Cushman Found. Foram. Res., vol. 5, p. 1, textfigs. 3-6. Redefined as subspecies by Bolli (1957a).

\section{Globigerina dutertrei d'Orbigny.}

G. dutertrei d'Orbigny, 1839 , p. 84. Lectotype described and figured by Banner \& Blow (1960, p. 11, pl. 2, fig. 1). Similar forms which could be referred to as $G$. eggeri Rhumbler or $G$. helicina d'Orbigny (see lectotypes in Banner \& Blow, 1960) are included here in $G$. dutertrei.

Globigerina galavisi Bermudez.

G. galavisi Bermudez, 1961, Bol. Geol. (Caracas), Publ. Especial 3, p. 1183, pl. 4, fig. 3. Holotype redrawn in Blow (1969, pl. 5, figs. 1-3).

Globigerina juvenilis Bolli.

G. juvenilis Bolli, 1957a, p. 110, pl. 24, figs. 5, 6 .

Globigerina linaperta Finlay.

G. linaperta Finlay, 1939, Trans. Proc. Roy. Soc. New Zealand, vol. 69 , p. 125 , pl. 13, figs. 54-57. Holotype refigured by Hornibrook (1958, p. 33, pl. 1, figs. 19-21).

Globigerina nepenthes Todd.

G. nepenthes Todd, 1957, U.S. Geol. Surv., Profess. Paper 280-H, p. 301, pl. 78, fig. 7.

Globigerina pera Todd.

G. pera Todd, 1957, U.S. Geol. Surv. Profess. Paper 280-H, p. 301, pl. 70, figs. $10,11$.

Globigerina prasaepis Blow.

G. prasaepis Blow, 1969, p. 382 , pl. 10, fig. 13; pl. 18 , figs. 3-7. Blow's figures are all ventral views; for a spiral view see Bolli (1957a, pl. 22, fig. 4a).

Globigerina sellii (Borsetti).

Globoquadrina sellii Borsetti, 1959, Giorn. Geol. (Bologna), ser. 2, vol. 27, p. 209, pl. 13, fig. 3. 
Globigerina senni (Beckmann).

Sphaeroidinella senni Beckmann, 1954, p. 394, pl. 26, figs. $2-4$; text fig. 20 .

Globigerina tapuriensis Blow \& Banner.

Globigerina tripartita tapuriensis Blow \& Banner, 1962, p. 97 , pl. 10 , figs. H-K.

Globigerina tripartita Koch.

Globigerina bulloides d'Orbigny var. tripartita Koch, 1926, Eclogae Geol. Helvetiae, vol. 19, p. 746, textfig. 21. Emended in Blow \& Banner (1962, p. 96).

Globigerina sp. A (Plate 1, Figures 1-4).

The test shows 3 to 3.5 chambers in the last whorl. The average maximum diameter is 0.35 to 0.4 millimeters. The aperture is low, slit-like, without a distinct lip. This form resembles $G$. linaperta Finlay and $G$. pseudoeocaena var. trilobata Subbotina, but is more compact than the former and has a rather more closed umbilicus and narrower aperture than the latter. It is a common species in the Oligocene (see range charts, Sites 69, 70, and 72).

Globigerinoides fistulosus (Schubert).

Globigerina fistulosa Schubert, 1910, Verh. K. K. Geol. Reichsanst., p. 323, textfig. 2.

Globigerinoides primordius Blow \& Banner.

Globigerinoides quadrilobatus primordius Blow \& Banner, 1962, p. 115, pl. 9, figs. Dd-Ff; textfig. 14 (iii-viii).

Globigerinoides ruber (d'Orbigny).

Globigerina rubra d'Orbigny, 1839, p. 82. Lectotype described and figured by Banner \& Blow (1960, p. 19, pl. 3, fig. 8). Similar forms in the Lower and Middle Miocene are recorded as $G$. subquadratus (see Cordey, 1967).

Globigerinoides sicanus de Stefani.

G. sicanus de Stefani, 1950, Plinia (Palermo), vol. 3, note 4 , p. 9. Holotype refigured by Blow (1969, p. 326 , pl. 3 , figs. 10,11 ).

G. bisphericus Todd 1954 is a junior synonym (see Banner \& Blow, 1965).

Globigerinoides subquadratus Brönnimann.

G. subquadratus Bronnimann, in: Todd et al., 1954, Am. J. Sci., vol. 252, p. 680 , pl. 1, fig. 5.

Globigerinatella insueta Cushman \& Stainforth.

G. insueta Cushman \& Stainforth, 1945, Cushman Lab. Foram. Res., Spec. Publ. no. 14, p. 69, pl. 13, figs. 7-9.

Globoquadrina altispira altispira (Cushman \& Jarvis). Globigerina altispira Cushman \& Jarvis, 1936, Contrib. Cushman Lab. Foram. Res., vol. 12, p. 5, pl. 1, figs. 13, 14.
Globoquadrina altispira globosa Bolli. Globoquadrina altispira globosa Bolli, 1957a, p. 111, pl. 24, figs. 9, 10 .

Globoquadrina altispira globularis Bermudez.

Globoquadrina globularis Bermudez, 1961, Bol. Geol. (Caracas), Publ. Especial 3, p. 1311, pl. 13, figs. 4-6.

Globoquadrina dehiscens dehiscens (Chapman, Parr \& Collins).

Globorotalia dehiscens Chapman, Parr \& Collins, 1934, J. Zool. (London), vol. 38 , no. 262, p. 569, pl. 11, fig. 36.

Globoquadrina dehiscens advena Bermudez.

Globoquadrina quadraria (Cushman \& Ellisor) var. advena Bermudez, 1949, Cushman Lab. Foram, Res., Spec. Publ. no. 25 , p. 287 , pl. 22, figs. $36-38$.

Globoquadrina praedehiscens Blow \& Banner.

Globoquadrina dehiscens praedehiscens Blow \& Banner, 1962, p. 116, pl. 15 figs. Q-S.

Globorotalia acostaensis Blow.

G. acostaensis Blow, 1959, Bull. Am. Paleont., vol. 39, no. 178 , p. 208 , pl. 17 , figs. $106,107$.

Globorotalia archaeomenardii Bolli.

G. archaeomenardii Bolli, 1957a, p. 119, pl. 28, fig. 11 .

Globorotalia brevispira (Subbotina).

Globigerina brevispira Subbotina, 1961, Mikrofauna SSSR, Sbornik XI, p. 65, pl. 11, figs. 4-6.

Globorotalia crassaformis ronda Blow.

Globorotalia (T.) crassaformis ronda Blow, 1969, p. 388 , pl. 4 , figs. $4-6$; pl. 37 , figs. 6-9.

Globorotalia cultrata (d'Orbigny).

Rotalina cultrata d'Orbigny, 1839, p. 76. Neotype described and figured by Banner \& Blow (1960, p. 34, pl. 6, fig. 1).

Globorotalia exilis Blow.

Globorotalia (Globorotalia) cultrata exilis Blow, 1969, p. 369 , pl. 7 , figs. $1-3$; pl. 42 , figs. 1,5 .

Globorotalia fohsi fohsi Cushman \& Ellisor.

Globorotalia fohsi Cușhman \& Ellisor, 1939, Contrib. Cushman Lab. Foram. Res., vol. 15, p. 12, pl. 2, fig. 6. Holotype refigured by Blow \& Banner (1966, pl. 1, fig. 5). In the present report, the name G. fohsi fohsi is applied to fully keeled specimens exclusive of $G$. $f$. lobata and $G$. f. robusta (see Bolli 1967). It is regrettable that the uncertainties relating to the provenance and nature of the types of $G$. fohsi have led to conflicting interpretations of this taxon (Bolli, 1950; Blow \& Banner, 1966). The writer does not wish to enter into these discussions, but would like to add 
that, since he has recently seen the holotype of $G$. fohsi, he supports Bolli's suspicion that the name fohsi (sensus stricto) might have to be applied to partially keeled forms in particular. In this case $G$. $f$. praefohsi would become a junior synonym of $G$. foshi.

Globorotalia fohsi lobata Bermudez.

Globorotalia lobata Bermudez, 1949, Cushman Lab. Foram. Res., Spec. Publ. no. 25, p. 286, pl. 22, figs. 15-17. This subspecies comprises fully keeled forms with distinctly lobate chambers.

Globorotalia fohsi peripheroacuta Blow \& Banner. Globorotalia (Turborotalia) peripheroacuta Blow \& Banner, 1966, p. 294, pl. 1, fig. 2; pl. 2, figs. 4-5, 13.

Globorotalia fohsi peripheroronda Blow \& Banner. Globorotalia (Turborotalia) peripheroronda Blow \& Banner, 1966, p. 294, pl. 1, fig. 1; pl. 2, figs. 1-3.

Globorotalia fohsi praefohsi Blow \& Banner. Globorotalia (Globorotalia) praefohsi Blow \& Banner, 1966, p. 295, pl. figs. 3, 4; pl. 2, figs. 6, 7, 10, 11.

Globorotalia fohsi robusta Bolli.

Globorotalia fohsi robusta Bolli, 1950, Contrib. Cushman Found. Foram. Res., vol. 1, p. 84, 89; pl. 15, fig. 3 ; textfig. 2. This name is applied to mainly planoconvex forms with a thick keel, which are the youngest members of the $G$. fohsi lineage.

Globorotalia gemma Jenkins.

G. gemma Jenkins, 1965, New Zealand J. Geol. Geophys., vol. 8, p. 1115, fig. 11, nos. 97-103.

Globorotalia humerosa Takayanagi \& Saito.

G. humerosa Takayanagi \& Saito, 1962, Sci. Repts. Tohoku Univ., 2nd ser., Spec. Vol., no. 5, p. 78, pl. 28, figs. 11,12 .

Globorotalia kugleri Bolli.

G. kugleri Bolli, 1957a, p. 118, pl. 28, figs. 5, 6.

Globorotalia margaritae Bolli \& Bermudez.

G. margaritae Bolli \& Bermudez, 1965, p. 139, pl. 1, figs. 16-18.

Globorotalia mayeri Cushman \& Ellisor.

G. mayeri Cushman \& Ellisor, 1939, Contrib. Cushman Lab. Foram. Res., vol. 15, p. 11, pl. 2, fig. 4. In this Report, Globorotalia siakensis (LeRoy) is combined with $G$. mayeri, because it was difficult to separate the two species in many of the larger populations. This procedure is considered justified, since the variability of neither G. mayeri nor G. siakensis is known in their respective type areas.

Globorotalia menardii (Parker, Jones \& Brady).

Rotalia menardii Parker, Jones \& Brady, 1865, Ann.
Mag. Nat. Hist., vol. 16, ser. 3, p. 20, pl. 3, fig. 81 . Lectotype described and figured by Banner \& Blow, 1960, p. 31, pl. 6, fig. 2.

Globorotalia merotumida Blow \& Banner.

Globorotalia (G.) merotumida Blow \& Banner, in: Banner \& Blow, 1965, Nature, vol. 207, no. 5004, p. 1352, fig. 1.

Globorotalia ef. miocenica Palmer (Plate 1, Figures 5, 6, 10).

Globorotalia menardii (d'Orbigny) var. miocenica Palmer, 1945, Bull. Am. Paleontol. vol. 29, no. 115, p. 70 , pl. 1, fig. 10. This form resembles $G$. miocenica from the Caribbean and is also mostly dextrally coiled, but it is less distinctly planoconvex in peripheral view. It is found rarely in the Pliocene (see range charts, Sites 72 and 73).

Globorotalia opima nana Bolli.

G. opima nana Bolli, 1957a, p. 118, pl. 28, fig. 3 .

Globorotalia opima opima Bolli.

G. opima opima Bolli, 1957a, p. 117, pl. 28, figs. 1, 2. Apart from the large typical form, we find smaller specimens (transitional to G. opima nana), which have a slightly longer range but are nevertheless stratigraphically useful. They are here referred to as $G$. opima s.l.

Globorotalia cf. plesiotumida Blow \& Banner (Plate 1, Figures 7-9).

Globorotalia (G.) tumida (Brady) plesiotumida Blow \& Banner, in: Banner \& Blow, 1965, Nature, vol. 207, no. 5004 , p. 1353 , fig. 2 . The form here referred to as $G$. cf. plesiotumida is found in the Upper Miocene of Sites 71,72 and 73, just below the earliest appearance of $G$. tumida (see also range charts, Sites 71 and 72). It appears to be distinctly flatter than the specimens from Cubagua (Banner \& Blow, 1965; Bermudez \& Bolli, 1969). These authors assume that $G$. plesiotumida evolves into G. tumida, but full documentation of this evolution has not yet been presented. Unfortunately, G. tumida is absent in the Upper Miocene/Pliocene of Cubagua and other Caribbean areas (see also DSDP Leg 4 Report on Foraminifera by Bolli, 1970). In the Central Pacific samples, large and robust specimens of G. tumida appear rather abruptly. Possibly, the transition from $G$. plesiotumida to $G$. tumida took place in such a short time that it was not recorded in the available samples.

Globorotalia pseudokugleri Blow.

Globorotalia (Turborotalia) pseudokugleri Blow, 1969, p. 391 , pl. 10, figs. $4-6$; pl. 39 , figs. 5, 6 .

Globorotalia pseudopima Blow.

Globorotalia (Turborotalia) acostaensis pseudopima Blow, 1969 , p. 387, pl. 35, figs. 1-7. 
Globorotalia spinuloinflata (Bandy).

Bandy, 1949, Bull. Am. Paleontol. vol. 32, no. 131, p. 122, pl. 23, fig. 1 .

Globorotalia spinulosa Cushman.

G. spinulosa Cushman, 1927, Contrib. Cushman Lab.

Foram. Res., vol. 3, p. 114, pl. 23, fig. 4.

Globorotalia tosaensis Takayanagi \& Saito.

G. tosaensis Takayanagi \& Saito, 1962, Sci. Repts. Tohoku Univ., 2nd ser., Spec. Vol. no. 5, p. 81, pl. 28, figs. 11,12 .

Globorotalia truncatulinoides (d'Orbigny).

Rotalina truncatulinoides d'Orbigny, 1839, in: Barker-

Webb \& Berthelot; Hist. Nat. Iles. Canaries, vol. 2, pt.

2, pl. 2, figs. 25-27. Neotype described and figured by

Blow (1969, p. 403, pl. 5, figs. 10-12).

Globorotalia tumida (Brady).

Pulvinutina menardii (d'Orbigny) var. tumida Brady, 1877, Geol. Mag., n. s., vol. 4, p. 535. Lectotype designated by Banner \& Blow, 1960, p. 26, pl. 5, fig. 1 . The variety flexuosa (Koch) is included in this species.

Globorotalia wilsoni (Cole).

Globigerina wilsoni Cole, 1927, Bull. Am. Paleontol. vol. 14 , no. 51 , p. 34 , pl. 4 , figs. 8,9 . This species includes Globorotalia bolivariana (Petters) of Bolli (1957b).

Globorotaloides sp. A. (Plate 1, Figures 11-13).

This form is larger and flatter than Globorotaloides suteri Bolli. The maximum diameter is 0.4 to 0.6 millimeter. The last whorl usually consists of five to six chambers. In most specimens, a small bulla-like chamber covers the umbilicus. This characteristic species appears to be a good marker within the Oligocene of this area (see range charts, Sites 72,73 and 74.

Orbulina suturalis Brönnimann.

O. suturalis Bronnimann, 1951, Contr. Cushman Found. Forma. Res., vol 2, p. 135, textfig. 2-4.

Orbulina universa d'Orbigny.

O. universa d'Orbigny, 1839, in: Barker-Webb \& Berthelot, Hist. Nat. Iles. Canaries, vol. 2, pt. 2, p. 123, pl. 1, fig. 1.

Praeorbulina glomerosa (Blow).

Porticulasphaera glomerosa glomerosa Blow, 1956, Micropaleontology, vol. 2, p. 65 , textfig. 1, nos. 15-19; textfig. 2, nos. 1,2 . In this report $P$. glomerosa also includes $P$. glomerosa circularis and $P$. glomerosa curva, described by Blow in the same paper.
Pseudohastigerina barbadoensis Blow.

P. barbadoensis Blow, 1969, p. 409, pl. 53, figs. 7-9; pl. 54 , figs. 1-3.

Pulleniatina finalis Banner \& Blow.

Pulleniatina obliquiloculata finalis Banner \& Blow, 1967, p. 140, pl. 2, figs. 4-10; pl. 3, fig. 5; pl. 4, fig. 10.

Pulleniatina obliquiloculata (Parker \& Jones).

Pullenia sphaeroides (d'Orbigny) var. obliquiloculata Parker \& Jones, 1865, Phil. Trans. Roy. Soc. London, vol. 155 , p. 365,368 ; pl. 19 , fig. 4 . Lectotype selected by A. R. Loeblich and illustrated by Banner \& Blow (1960, pl. 7, fig. 4). The two subspecies $P$. obliquiloculata obliquiloculata and P. o. praecursor of Banner \& Blow (1967) are here combined.

Pulleniatina primalis Banner \& Blow.

P. primalis Banner \& Blow, 1967, p. 142, pl. 1, figs. 3-8; pl. 3, fig. 2.

Pulleniatina spectabilis Parker.

P. spectabilis Parker, 1965, Contrib. Cushman Found. Foram. Res., vol, 16, p. 151, textfigs. 1-4.

Sphaeroidinella dehiscens (Parker \& Jones).

Sphaeroidina bulloides d'Orbigny var. dehiscens Parker \& Jones, 1865, Phil. Trans. Roy. Soc. London, vol. 155 , p. 369 , pl. 19 , fig. 5 . Lectotype described and figured by Banner \& Blow (1960, p. 35, pl. 7, fig. 3). The "forma immatura (Cushman)" and the subspecies excavata Banner and Blow nos. 114 and 115 in Blow, 1969) are not separated here from this species.

Sphaeroidinellopsis paenedehiscens Blow.

Sphaeroidinellopsis subdehiscens paenedehiscens Blow, 1969 , p. 386, pl. 30 , figs. $4,5,9$.

Sphaeroidinellopsis seminulina (Schwager).

Globigerina seminulina Schwager, 1866, Novara Exped. 1857-1859, Geol. Theil, Bd. 2, Abth. 2, p. 286, pl. 7, fig. 112. Neotype described and figured by Banner \& Blow, 1960, p. 24, pl. 7, fig. 2. This species name is used in the sense of Parker (1967).

Sphaeroidinellopsis subdehiscens (Blow).

Sphaeroidinella dehiscens subdehiscens Blow, 1959, Bull. Am. Paleontol. vol. 39, no. 178, p. 195, pl. 12, figs. 71,72 .

Truncorotaloides rohri Brönnimann \& Bermudez.

T. rohri Bronnimann \& Bermudez, 1953, J. Paleontol., vol. 27 , p. 818, pl. 87, figs. 7-9. 
Turborotalita humilis (Brady).

Truncatulina humilis Brady, 1884, Rept. Voy. Challenger, Zoology, vol. 9, p. 665, pl. 94, fig. 7. Lectotype described and illustrated by Banner \& Blow (1960, p. 36, pl. 8, fig. 1).

\section{Benthonic Foraminifera}

Alabamina dissonata (Cushman \& Renz).

Pulvinulinella atlantisae Cushman var. dissonata Cushman \& Renz, 1948, Cushman Lab. Foram. Res., Spec. Publ. no. 24, p. 35, pl. 7, figs. 11, 12.

Anomalina dorri aragonensis Nuttall.

Anomalina dorri Cole var. aragonensis Nuttall, 1930, J. Paleontol., vol 4, p. 291, pl. 24, fig. 18; pl. 25, fig. 1.

Nuttallides truempyi (Nuttall).

Eponides trumpyi Nuttall, 1930, J. Paleontol., vol. 4, p. 274,287 ; pl. 24 , figs. $9,13,14$.

Spiroplectammina trinitatensis Cushman \& Renz.

S. trinitatensis Cushman \& Renz, 1948, Cushman Lab. Foram. Res., Spec. Publ. no. 24, p. 11, pl. 2, figs. 13, 14.

\section{REFERENCES}

Banner, F. T. and Blow, W. H., 1960. Some primary types of species belonging to the Superfamily Globigerinacea. Contrib. Cushman Found. Foram. Res., $11,1$.

1965. Progress in the planktonic foraminiferal biostratigraphy of the Neogene. Nature. 208 (5016), 1164.

1967. The origin, evolution and taxonomy of the foraminiferal genus Pulleniatina Cushman, 1927. Micropaleontology. 13, 133.

Beckmann, J. P., 1954. Die Foraminiferen der Oceanic Formation (Eocaen-Oligocene) von Barbados, Kl. Antillen. Eclog. Geol. Hel., 46 (1953), 301.

Berger, W. H., 1968. Planktonic foraminifera: selective solution and paleoclimatic interpretation. Deep-Sea Res., 15, 31.

Berggren, W. A., 1969. Rates of evolution in some Cenozoic planktonic foraminifera. Micropaleontology. 15, 351 .

Berggren, W. A. and Boersma, A., 1969. Late Pleistocene and Holocene planktonic foraminifera from the Red Sea. In: Hot Brines and Recent Heavy Mineral Deposits in the Red Sea. E. T. Degens and D. A. Ross (Eds.). New York (Springer), 282p.

Bermudez, P. J. and Bolli, H. M., 1969. Consideraciones sobre los sedimentos del Mioceno Medio al Reciente de las costas central y oriental de Venezuela. Tercera parte. Los Foraminiferos planctonicos. Bol. Geol. (Caracas). 10 (20), 137.
Blow, W. H., 1969. Late Middle Eocene to Recent planktonic foraminiferal biostratigraphy. Proc. First Intern. Conf. Planktonic Microfossils (Geneva, 1967). 1, 199.

Blow W. H. and Banner, F. T., 1962. The Mid-Tertiary (Upper Eocene to Aquitanian) Globigerinaceae. In: Fundamentals of Mid-Tertiary Stratigraphical Correlation. Cambridge (Cambridge University Press), $61 \mathrm{p}$.

1966. The morphology, taxonomy and biostratigraphy of Globorotalia barisanensis LeRoy, Globorotalia fohsi Cushman and Ellisor, and related taxa. Micropaleontology. 12, 286.

Bolli, H. M., 1950. The direction of coiling in the evolution of some Globorotaliidae. Gontrib. Cushman Found. Foram. Res. 1, 82.

, 1957a. Planktonic foraminifera from the Oligocene-Miocene Cipero and Lengua Formations of Trinidad, B.W.I. U. S. Nat. Museum Bull. 215, 97.

1957b. Planktonic foraminifera from the Eocene Navet and San Fernando Formations of Trinidad, B. W. I. U. S. Nat. Museum Bull. 215, 155. 1966. Zonation of Cretaceous to Pliocene marine sediments based on planktonic foraminifera. Bol. Inform. Asoc. Venezolana Geol. Min. Petrol (Caracas). 9, 3 .

1967. The subspecies of Globorotalia fohsi Cushman and Ellisor and the zones based on them. Micropaleontology. 13, 502 .

Bolli, H. M. and Bermudez, P. J., 1965. Zonation based on planktonic Foraminifera of the Middle Miocene to Pliocene warm-water sediments. Bol. Inform. Asoc. Venezolana Geol. Min. Petrol. 8, 121.

Cordey, W. G., 1967. The development of Globigerinoides ruber (D'Orbigny, 1839) from the Miocene to Recent. Palaeontology. (London). 10, 647.

D'Orbigny, A., 1839. Foraminiferes. In: Histoire Physique, Politique et Naturelle de I'lle de Cuba. Bertrand (Paris), $224 \mathrm{p}$.

Hays, J. D. et al., 1969. Pliocene-Pleistocene sediments of the Equatorial Pacific: their paleomagnetic, biostratigraphic, and climatic record. Bull. Geol. Soc. Am. 80, 1481 .

Hornibrook, N. de B., 1958. New Zealand Upper Cretaceous and Tertiary foraminiferal zones and some overseas correlations. Micropaleontology. 4, 25 .

Jenkins, D. G., 1966. Planktonic foraminiferal datum planes in the Pacific and Trinidad Tertiary. New Zealand J. Geol. Geophys. 9, 424.

Parker, F. L., 1967. Late Tertiary biostratigraphy (planktonic foraminifera) of tropical Indo-Pacific deep-sea cores. Bull. Am. Paleontol. 52 (235), 111. 



\section{PLATE 1}

Figures 1-4 Globigerina sp. A. From Sample 72-9-3, 48-50 cm. $100 \mathrm{X}$.

1 \& 2: spiral views showing two characteristic test shapes.

3: umbilical view.

4: oblique side view.

Figures 5, 6, 10 Globorotalia cf. miocenica Palmer. From Sample $73-6-2,48-50 \mathrm{~cm} .70 \mathrm{X}$.

5: spiral view.

6: umbilical view.

10: side view.

Figures 7-9 Globorotalia cf. plesiotumida Blow \& Banner. From Sample $71-4$, core catcher. $65 X$.

7: umbilical view (slightly oblique).

8: edge view.

9: spiral view.

Figures 11-13 Globorotaloides sp. A. From Sample 74-11-2, 28-30 cm. 100X.

11: spiral view.

12: side view.

13: umbilical view with bulla.

All figures on this plate are stereoscan photos. Each view represents a different specimen. 
PLATE 1
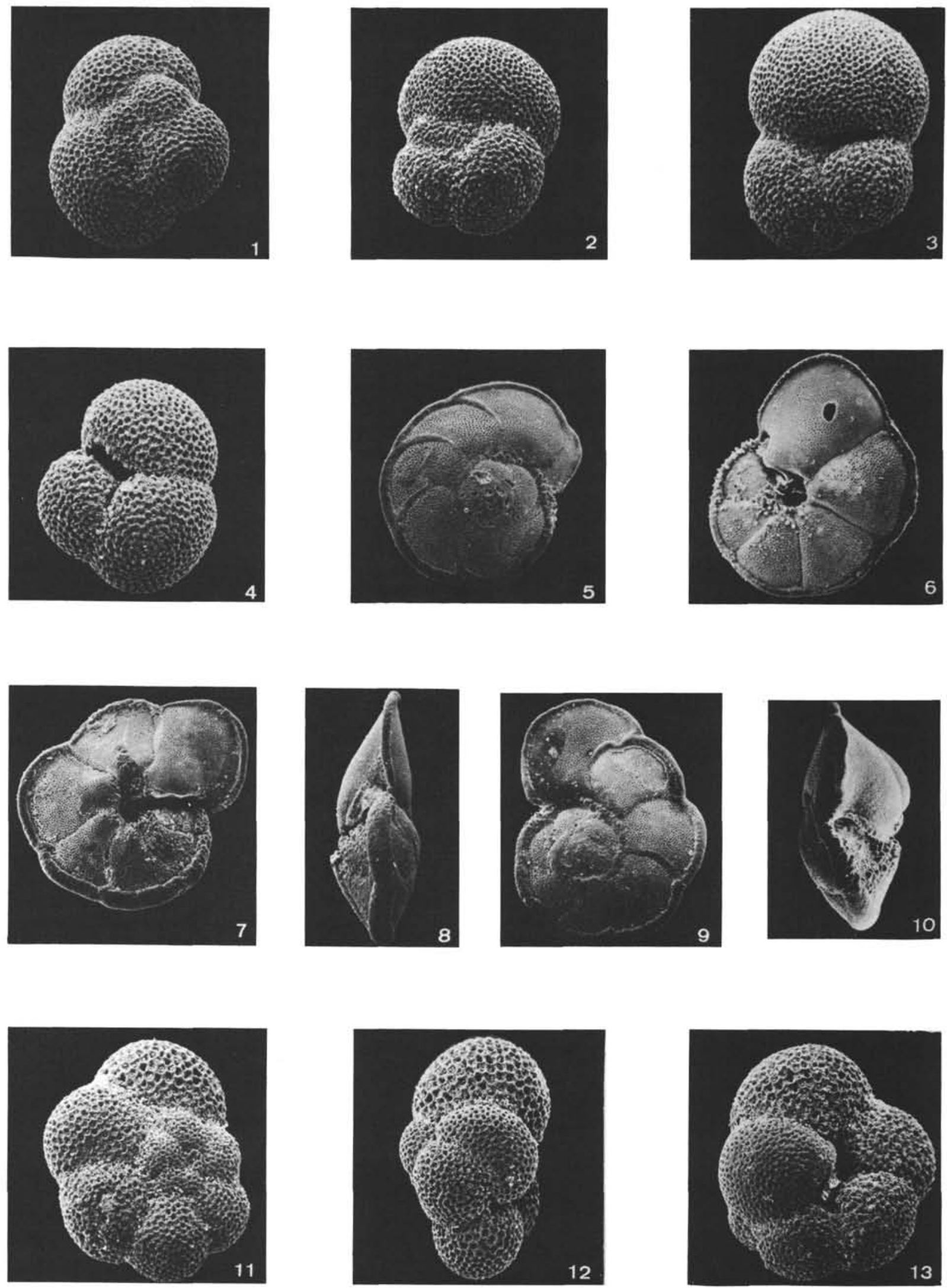